\title{
Effect of Supplementary Feeding of Concentrates and of Restricted Grazing on Holstein Heifers on Intensively Managed Grasspastures $^{1}$
}

\author{
R. Caro-Costas and J. Vicente-Chandler ${ }^{2}$
}

\begin{abstract}
Holstein heifers grazing unrestrictedly at 9 head/ha on steep, intensively managed grass pastures in the humid mountain region, and receiving no concentrate feed, gained $0.59 \mathrm{~kg} / \mathrm{head}$ daily over a 240 day period. Heifers which received an additional $2.3 \mathrm{~kg} / \mathrm{head} /$ day of concentrates gained 0.69 $\mathrm{kg} / \mathrm{head} / \mathrm{day}$, and carrying capacity of the pastures was increased to 12 head/ha. Heifers grazing for only 8 hours/day, and fed $3.6 \mathrm{~kg} / \mathrm{head} / \mathrm{day}$ of concentrates gained $0.75 \mathrm{~kg} / \mathrm{head} /$ day and carrying capacity of the pastures was increased to 15 head/ha. It was not economically beneficial to increase weight gains or carrying capacity of the pastures by feeding concentrates or by restricting grazing.

In a 360-day experiment, during a 90-day period between all-grass rations, heifers fed only on pasture gained $0.58 \mathrm{~kg} / \mathrm{head} /$ day and those that grazed for 6 hours/day and were fed $2.3 \mathrm{~kg} / \mathrm{head} /$ day of concentrates made similar gains averaging $0.53 \mathrm{~kg} / \mathrm{head} /$ day. However, heifers removed from the pastures during this period and fed $6 \mathrm{~kg}$ of bulky feed/head/day gained only $0.23 \mathrm{~kg} / \mathrm{head} /$ day. When all three groups were returned to a full grass ration, those previously fed only on grass averaged $0.46 \mathrm{~kg} / \mathrm{head} / \mathrm{day}$; those fed on bulky feed during the previous 90 days gained at a similar rate of $0.41 \mathrm{~kg} /$ head/day, but those previously on restricted grazing plus concentrates gained only $0.32 \mathrm{~kg} / \mathrm{head} /$ day. Overall average gains for the 360-day period were $0.54,0.43$ and $0.49 \mathrm{~kg} / \mathrm{head} /$ day for these three feeding regimes, respectively. It was more economically beneficial to feed concentrates and to restrict grazing than to put the heifers on a full ration of bulky feed during periods of forage scarcity.
\end{abstract}

\section{INTRODUCTION}

About a quarter of a million hectares of rolling to steep lands in the humid mountains of Puerto Rico are not suited to mechanized cropping and require the protection from erosion that well-managed grasslands can provide. Efficient production is feasible on these lands because the pastures can be fertilized from the air or with broad based tractors; cattle do their own harvesting. Since concentrate feed is imported and expensive, it should be used as little as possible in the feeding of cattle on the Island.

In densily populated Puerto Rico, efficient grassland farming requires heavy fertilization and intensive management as shown by Vicente-Chan-

\footnotetext{
${ }^{1}$ This paper covers investigations conducted cooperatively by the Science and Education Administration, USDA and the Agricultural Experiment Station, Mayagüez Campus, University of Puerto Rico, Río Piedras, P.R.

${ }^{2}$ Agronomist, cooperative between the Science and Education Administration, USDA and the Agricultural Experiment Station, Mayagüez Campus and Location Leader-Soil Scientist, Science and Education Administration, USDA, Río Piedras, P.R., respectively.
} 
dler et al. ${ }^{3}$ With Napier grass pastures, weight gains increased from 638 to $1,201 \mathrm{~kg} / \mathrm{ha} / \mathrm{yr}$ as fertilization was increased from 675 to $2,025 \mathrm{~kg} / \mathrm{ha} /$ yr. Pangola grass pastures responded to fertilization with 14-4-10 up to $2,688 \mathrm{~kg} / \mathrm{ha} / \mathrm{yr}$ and produced gains in weighed of $976 \mathrm{~kg} / \mathrm{ha} / \mathrm{yr}$. Star grass pastures produced $977,1,292$ and $1,472 \mathrm{~kg} / \mathrm{ha} / \mathrm{yr}$ of weight gains with $1,792,3,136$ and $4,480 \mathrm{~kg} / \mathrm{ha} / \mathrm{yr}$ of $15-5-10$ fertilizer, respectively. Under intensive management Pangola, Guinea and Napier grass pastures, produced similar weight gains averaging $1,181 \mathrm{~kg} / \mathrm{ha} / \mathrm{yr}$, total digestible nutrients averaging $8,466 \mathrm{~kg} / \mathrm{ha} / \mathrm{yr}$, and carrying capacities averaging 6.1 $273 \mathrm{~kg}$ steers/ha. Star grass produced an average of $1,514 \mathrm{~kg}$ of weight gain/ha/yr and had a carrying capacity of $7.4273 \mathrm{~kg}$ steers/ha. Crude protein content of the forage consumed by heifers grazing these intensively managed pastures was rarely less than $15 \%$, and digestibility of the forage averaged about $55 \%$.

In Puerto Rico, grasslands produce little more than half as much forage during the cooler winter months when rainfall is lower and days slightly shorter than during the rest of the year, but quality of the forage consumed by the grazing animals is not markedly affected. This seasonal variation in grassland production poses a serious management problem.

This paper presents the results of two experiments conducted on intensively managed grass pastures to determine the effect on animal weight gains and carrying capacity of the pastures of different levels, and methods of supplementary feeding of concentrates, and of restricted grazing.

\section{MATEREALS AND METHODS}

The experiments were conducted at Orocovis, which is at an elevation of about $600 \mathrm{~m}$. Average annual temperature is about $24^{\circ} \mathrm{C}$. Maximum daily temperature rarely exceed $31^{\circ} \mathrm{C}$ and minimum is rarely less than $19^{\circ} \mathrm{C}$ with average monthly fluctuations of $5^{\circ} \mathrm{C}$. Annual rainfall averages about $1,600 \mathrm{~mm}$ and is fairly well distributed except during January through March, when the climate is fairly dry and cooler. The Humatas clay soil (an Ultisol) on 30\% slopes was limed to about $\mathrm{pH} 6$.

A Napier grass pasture was fertilized every 3 mo with $1,000 \mathrm{~kg} / \mathrm{ha}$ of 15-5-10. The pasture was divided into enclosures which were grazed in rotation by three groups of young Holstein heifers. The heifers weighed about $180 \mathrm{~kg}$ initially. They were randomly assigned to the three treatments tested in each experiment. The heifers were treated for parasites and had access to common salt and fresh water at all times. They were weighed periodically, as required by the experiment.

${ }^{3}$ Vicente-Chandler, J., Abruña, F., Caro-Costas, R., Figarella, J., Silva, S., and Pearson, R. W., Intensive Grassland Management in the Humid Tropics of Puerto Rico, Agr. Exp. Stn., Univ. P.R., Bull, 233, Feb. 1974. 


\section{EXPERIMENT NO. 1}

The heifers were divided at random into three groups of 9,12 and 15 animals each and assigned to the following treatments for 240 days:

1. Nine heifers were fed exclusively on the grass pastures throughout the experiment.

2. Twelve heifers were grazed on the pastures at all times but received in addition $2.3 \mathrm{~kg}$ of a $15 \%$ crude protein ration/head/day.

3. Fifteen heifers were grazed only $8 \mathrm{hr} /$ day ( 7 a.m. to 3 p.m.) and were fed $3.6 \mathrm{~kg}$ of a $15 \%$ crude protein ration per head daily.

\section{EXPERIMENT NO. 2}

Holstein heifers were divided at random into three groups of eight animals each and assigned to the following treatments:

1. The first group grazed for 360 days with no concentrate feed.

2. The second group grazed for 180 days, was removed from the

TABLE 1.-Effect of supplementary feeding of concentrates and of restricted grazing on weight gain made by young Holstein heifers grazing intensively managed grass pastures over a 240-day period

\begin{tabular}{lcccc}
\hline \multicolumn{1}{c}{ Treatments } & $\begin{array}{c}\text { Average gain } \\
\text { per head }\end{array}$ & $\begin{array}{c}\text { Average daily } \\
\text { gain/head }\end{array}$ & $\begin{array}{c}\text { Carrying } \\
\text { capacity }\end{array}$ & $\begin{array}{c}\text { Weight gain/ } \\
\text { head/ha }\end{array}$ \\
\hline & $K g$ & $K g$ & Head/ha & $K g$ \\
1. Unrestricted grazing & $142 \mathrm{~b}^{1}$ & $0.59 \mathrm{~b}$ & 9 & 1.278 \\
2. Unrestricted grazing $+2.3 \mathrm{~kg}$ & $166 \mathrm{a}$ & $0.69 \mathrm{a}$ & 12 & 1,992 \\
$\begin{array}{l}\text { conc/head/day } \\
\text { 3. } 8 \mathrm{~h} \mathrm{grazing}+3.6 \mathrm{~kg} \text { of conc/ } \\
\text { head/day }\end{array}$ & $180 \mathrm{a}$ & $0.75 \mathrm{a}$ & 15 & 2,700 \\
\hline
\end{tabular}

\footnotetext{
${ }^{1}$ Values followed by the same letter do not differ significantly at the $5 \%$ level.
}

pastures and fed exclusively with $6 \mathrm{~kg}$ of $14 \%$ crude protein bulky feed/ head/day for 90 days, then was returned to grazing alone for the last 90 days.

3. The third group grazed for 180 days, was restricted to 6 hours of grazing daily ( 8 a.m. to 2 p.m.) and fed $2.3 \mathrm{~kg}$ of a $15 \%$ crude protein ration per head daily for 90 days and then was returned to grazing alone for the last 90 days.

\section{RESULTS AND DISCUSSIONS}

Table 1 summarizes the results of Experiment No. 1. Heifers grazing unrestrictedly on pastures and receiving no concentrate feed (treatment 1) gained an average of $142 \mathrm{~kg} / \mathrm{head}$ during the 240 -day experiment with average daily gains in weight of $0.59 \mathrm{~kg} / \mathrm{head}$ for 9 head carried/ha.

Heifers with unrestricted grazing and receiving $2.3 \mathrm{~kg}$ of concentrate/ head daily (treatment 2) made significantly higher gains averaging 166 $\mathrm{kg} /$ head equivalent to average daily gains of $0.69 \mathrm{~kg} / \mathrm{head}$. Carrying 
capacity of the pastures was increased from 9 head/ha with treatment I to $12 \mathrm{head} / \mathrm{ha}$ with this feeding regime.

Heifers with grazing restricted to 8 hours daily and receiving $3.6 \mathrm{~kg}$ of concentrates/day gained an average of $180 \mathrm{~kg} / \mathrm{head}$ during the course of the experiment, equivalent to average daily gains of $0.75 \mathrm{~kg} / \mathrm{head}$. Gains in weight made by these heifers were significantly higher than those in treatment 1 , but did not differ significantly from those in treatment 2 . Carrying capacity of the pastures with this feeding regime was increased to 15 head/ha, compared to 9 and 12 head/ha for treatments 1 and 2 , respectively.

Total weight gains during the 240-day experiment were $1,278,1,992$ and $2,700 \mathrm{~kg} / \mathrm{ha}$ for treatments 1,2 and 3 , respectively.

Table 2 shows that total costs of concentrates and pastures for the 240 day experiment were $\$ 550, \$ 2,007$ and $\$ 3,401 /$ ha for treatments 1,2 and 3 , respectively. This is equivalent to a cost of 43 cents $/ \mathrm{kg}$ of weight gain for the heifers fed only on grass compared to $\$ 1.01 / \mathrm{kg}$ for those with unrestricted grazing plus $2.3 \mathrm{~kg}$ of concentrates/head/day and to $\$ 1.26$ / $\mathrm{kg}$ for those restricted to 8 hours of grazing and receiving $3.6 \mathrm{~kg}$ of concentrates/head/day.

It was clearly not economical to increase the carrying capacity of these pastures by supplementary feeding of concentrates or by restricting grazing to 8 hours daily and feeding cattle an even higher level of concentrates.

Table 3 summarizes the results of Experiment No. 2. During the first 180 days, when all three groups of heifers were fed only on pasture, weight gains were almost identical for all three groups averaging $0.55 \mathrm{~kg} / \mathrm{head} /$ day.

During the next 90 days the heifers fed only on pasture (treatment 1 ) gained an average of $0.58 \mathrm{~kg} / \mathrm{head} /$ day. Those grazed for only 6 hours daily but receiving $2.3 \mathrm{~kg}$ of concentrates/head/day (treatment 3) made similar weight gains averaging $0.53 \mathrm{~kg} / \mathrm{head} /$ day. On the other hand, the heifers removed from the pastures and fed $6 \mathrm{~kg} / \mathrm{head} /$ day of bulky feed (treatment 2) made significantly lower gains, averaging $0.23 \mathrm{~kg} / \mathrm{head}$ / day.

During the final 90 days when all 3 groups were returned to a full grass ration, those fed throughout the course of the experiment on grass only (treatment 1) averaged $0.46 \mathrm{~kg} / \mathrm{head} /$ day, and those fed only on bulky feed during the previous 90 days (treatment 2) gained at a similar rate of $0.41 \mathrm{~kg} / \mathrm{head} /$ day. On the other hand, the heifers on restricted grazing plus concentrate feed during the previous 90 days (treatment 3) made significantly lower gains, averaging only $0.32 \mathrm{~kg} / \mathrm{head} /$ day, probably due to the effect of withdrawal of the concentrate feed.

Average gains per head for the entire 360-day experiment were 192.5, 
TABLE 2.-Cost of feeding young Holstein heifers grazing intensively managed grass pastures with supplementary feeding of concentrates and restricted grazing over a 240-day period

\begin{tabular}{|c|c|c|c|c|c|c|}
\hline Treatments & $\begin{array}{c}\text { Total gain in } \\
\text { weight }\end{array}$ & $\begin{array}{c}\text { Concentrate } \\
\text { consumed }\end{array}$ & $\begin{array}{c}\begin{array}{c}\text { Cost of } \\
\text { concentrate }\end{array} \\
\end{array}$ & $\begin{array}{c}\text { Cost of } \\
\text { pasture }^{2}\end{array}$ & $\begin{array}{c}\text { Total cost } \\
\text { of feed }\end{array}$ & $\begin{array}{l}\text { Cost per unit o } \\
\text { gain in weight }\end{array}$ \\
\hline & $K g / h a$ & $\mathrm{Kg} / \mathrm{ha}$ & $\$ / h \alpha$ & $\$ / h a$ & $\$ / h a$ & $c / k g$ \\
\hline 1. Unrestricted grazing & 1,278 & 0 & 0 & 550 & 550 & $\$ 0.43$ \\
\hline $\begin{array}{l}\text { 2. Unrestricted grazing }+2.3 \mathrm{~kg} \text { conc/ } \\
\text { head/day }\end{array}$ & 1,992 & 6,664 & 1,457 & 550 & 2,007 & 1,01 \\
\hline $\begin{array}{l}\text { 3. } 8 \mathrm{~h} \text { grazing }+3.6 \mathrm{~kg} \text { of conc/head/ } \\
\text { day }\end{array}$ & 2,700 & 12,960 & 2,851 & 550 & 3,401 & 1.26 \\
\hline
\end{tabular}

\footnotetext{
' At 22 cents $/ \mathrm{kg}$.

${ }^{2}$ At a rate of $\$ 820 / \mathrm{ha} / \mathrm{yr}$.
} 
155.1 and $178.1 \mathrm{~kg} / \mathrm{head}$ for treatments 1,2 and 3 , respectively equivalent to $.53, .43$ and $.49 \mathrm{~kg} / \mathrm{head} /$ day. Gains in treatment 2 were significantly lower than those for treatments 1 and 3 .

Table 4 shows that over the 360 days of experimentation the 8 heifers fed only on grass pastures (treatment 1) gained a total of $1,540 \mathrm{~kg}$ which did not differ significantly from the $1,425 \mathrm{~kg}$ made by those with restricted grazing supplemented by concentrate feed during a 90 day period (treatment 3). However, the heifers receiving only bulky feed during the second

TABLE 3.-Weight gain of three groups of eight Holstein heifers, each with different feeding regimens, over 3 consecutive periods

\begin{tabular}{|c|c|c|c|c|}
\hline Treatment no & Feeding regime & $\begin{array}{c}\text { Total weight } \\
\text { gain }\end{array}$ & $\begin{array}{l}\text { Average gain/ } \\
\text { head }\end{array}$ & $\begin{array}{l}\text { Average daily } \\
\text { gain/head }\end{array}$ \\
\hline \multicolumn{5}{|c|}{$\begin{array}{c}K g \\
\text { First period (180 days) }\end{array}$} \\
\hline 1 & Grass only & 790 & 98.8 & $0.55 \mathrm{a}^{1}$ \\
\hline 2 & Grass only & 781 & 97.6 & $0.54 \mathrm{a}$ \\
\hline 3 & Grass only & 809 & 101.1 & $0.56 \mathrm{a}$ \\
\hline \multicolumn{5}{|c|}{ Second period (90 days) } \\
\hline 1 & Grass only & 420 & 52.5 & $0.58 \mathrm{a}$ \\
\hline 2 & $6 \mathrm{~kg}$ of bulky feed/head/day & 163 & 20.4 & $0.23 \mathrm{~b}$ \\
\hline 3 & $\begin{array}{l}6 \mathrm{~h} \text { grazing }+6 \text { kgs of Concentrate } \\
\text { feed/head/day }\end{array}$ & 384 & 48.0 & $0.53 \mathrm{a}$ \\
\hline \multicolumn{5}{|c|}{ Third period (90 days) } \\
\hline 1 & Grass only & 330 & 41.3 & $0.46 \mathrm{a}$ \\
\hline 2 & Grass only & 297 & 37.1 & $0.41 \mathrm{a}$ \\
\hline 3 & Grass only & 232 & 29.0 & $0.32 \mathrm{~b}$ \\
\hline \multicolumn{5}{|c|}{ Total for 3 periods (360 days) } \\
\hline 1 & As described above & 1,540 & 192.5 & $0.54 \mathrm{a}$ \\
\hline 2 & As described above & 1,241 & 155.1 & $0.43 \mathrm{~b}$ \\
\hline 3 & As described above & 1,425 & 178.1 & $0.49 a$ \\
\hline
\end{tabular}

'Values followed by the same letter do not differ significantly at the $5 \%$ level.

(90 days) period (treatment 2 ) made significantly lower total gains of $1,241 \mathrm{~kg}$.

Table 4 shows that total cost of feed during the 360-day experiment was $\$ 0.53 / \mathrm{kg}$ of weight gain for heifers fed only on grass (treatment 1 ), $\$ 1.18 / \mathrm{kg}$ for those fed on bulky feed alone during 90 days between two periods of all-grass rations, and $\$ 0.76 / \mathrm{kg}$ for those on restricted grazing plus concentrates during this period.

It was more economical to feed heifers concentrates and to restrict 
grazing (treatment 3 ) than to feed them entirely on bulky rations during periods of slow pasture growth.

\section{RESUMEN}

En un experimento que duró 240 Días, novillas Holstein alimentadas sólo con pastos administrados intensivamente en la región montañosa húmeda de Puerto Rico aumentaron de peso a razón de $.59 \mathrm{~kg} / \mathrm{cabeza}$ y día, manteniéndose 9 cabezas por hectárea. Las novillas que además del pasto recibieron $2.3 \mathrm{~kg}$ de alimento concentrado por cabeza y día aumentaron $.69 \mathrm{~kg}$ por cabeza y día manteniéndose 12 cabezas/ha. Las novillas a las cuales se les permitió sólo 8 horas diarias de pastoreo, además de recibir $3.6 \mathrm{~kg}$ de alimento concentrado por cabeza y día, aumentaron $.75 \mathrm{~kg}$ por cabeza y dá, manteniéndose 15 cabezas/ha. No

TABLE 4.-Cost of feeding three groups of eight Holstein heifers each over a 360-day period with different feeding regimes

\begin{tabular}{|c|c|c|c|c|c|c|}
\hline $\begin{array}{l}\text { Treat- } \\
\text { ment }^{1}\end{array}$ & $\begin{array}{c}\text { Total gain } \\
\text { weight }\end{array}$ & $\begin{array}{c}\text { Concentrate } \\
\text { feed consumed }\end{array}$ & $\begin{array}{l}\text { Cost of concen- } \\
\text { trate feed }^{2}\end{array}$ & Cost of grassi & Total cost & $\begin{array}{l}\text { Cost/unit weight } \\
\text { gain }\end{array}$ \\
\hline & $K g$ & $\mathrm{Kg}$ & $\$$ & $\$$ & $\Phi$ & $\$ / k g$ \\
\hline 1 & $1,540 \mathrm{a}^{4}$ & 0 & 0 & 820 & 820 & 0.53 \\
\hline 2 & $1,241 \mathrm{~b}$ & 4,320 & 855 & 615 & 1,470 & 1.18 \\
\hline 3 & $1,425 \mathrm{a}$ & 1,657 & 364 & 718 & 1,082 & 0.76 \\
\hline
\end{tabular}

${ }^{1}$ Treatment $1-$ Grazed on grass pastures for all 360 days of experimentation. Treatment 2-Grass pastures for first 180 days, $6 \mathrm{~kg} / \mathrm{head} /$ day of $14 \%$ protein bulky feed and no grazing for 90 days; grass pastures only for final 90 days. Treatment 3-Grass pastures for 180 days; $6 \mathrm{~h}$ of daily grazing $+2.3 \mathrm{~kg} / \mathrm{head} /$ day of $15 \%$ protein fitting ration for 90 days; grass pastures for final 90 days.

${ }^{2}$ At 19.8 cents $/ \mathrm{kg}$ of bulky feed and 22 cents $/ \mathrm{kg}$ of concentrate feed.

${ }^{3}$ Cost of producing forage $=\$ 820 / \mathrm{ha} / \mathrm{yr}$. Treatment $2=$ discounted $25 \%$ for 3 mo when heifers were fed bulky feed only. Treatment $3=$ estimated forage consumption reduced to $1 / 2$ during 3 months when pastures were grazed only $6 \mathrm{~h}$ daily.

${ }^{4}$ Values followed by the same letter do not differ significantly at the $5 \%$ level.

resultó económico aumentar las ganancias de peso de las novillas o el numero de cabezas que el pasto puede mantener mediante alimentación suplementaria con alimentos concentrados o limitando las horas de pastoreo.

En otro experimento, las novillas que se alimentaron sólo con pasto durante un período de 90 días entre 2 períodos en que fueron alimentadas solamente con pasto, aumentaron a razón de $.58 \mathrm{~kg}$ por cabeza y día. Las novillas que durante ese perpaaiodo de 90 días pastaron durante sólo 6 horas al día, además de recibir $2.3 \mathrm{~kg}$ de alimento concentrado por cabeza y día, tuvieron similares aumentos de peso, que en promedio ascendieron a $.53 \mathrm{~kg}$ por cabeza y día. Sin embargo, las novillas que se retiraron de los pastos durante ese período y se alimentaron con $6 \mathrm{~kg}$ de alimento voluminoso ("bulky") por cabeza y día aumentaron sólo $.23 \mathrm{~kg}$ 
por cabeza y día. Cuando todas las novillas volvieron a alimentarse con pasto, las alimentadas previamente con pasto sólo aumentaron .46 kg por cabeza y día, las alimentadas sólo con alimento voluminoso ("bulky") durante los 90 días anteriores aumentaron $.41 \mathrm{~kg}$ por cabeza y día, pero las que habían sido restringidas a 6 horas de pastoreo además de recibir alimento concentrado aumentaron sólo $.32 \mathrm{~kg}$ por cabeza y día. Tomado en conjunto, durante los 360 días que duró el experimento las novillas aumentaron a razón de $.53, .43$ y $.49 \mathrm{~kg}$ por cabeza y día con estos tres regímenes alimenticios, respectivamente. Resultó más económico alimentarlas con alimento concentrado combinado con pastoreo límitado que exclusivamente con alimento voluminoso ("bulky") durante períodos en que el pasto escasea. 